論文特集「フッ素の化学とその応用」

（日本化学会誌, 1985, (10), p. 1783 1789)

(C) 1985 The Chemical Society of Japan

\title{
フッ化物ガラス $\mathrm{ZrF}_{4}-\mathrm{BaF}_{2}-\mathrm{MF}_{n}(\mathrm{M}:$ 第 $\mathrm{I} \sim \mathrm{V}$ 族金属元素 $)$ の イオン伝導度
}

(1985 年 2 月 18 日 受理)

河 本 洋 二**野 原一 郎

$\mathrm{ZrF}_{4}-\mathrm{BaF}_{2}-\mathrm{MF}_{n}$ 三成分系ガラスを研究対象として， $\mathrm{ZrF}_{4}$ 系ガラスにおけるフッ化物イオン层導と ガラス構成成分との関係を検討した。 $\mathrm{MF}_{n}$ として第 $\mathrm{I}$ 族から第 $\mathrm{V}$ 族の金属フッ化物 12 種， $\mathrm{LiF}, \mathrm{NaF}$, $\mathrm{RbF}, \mathrm{CsF}, \mathrm{CaF}_{2}, \mathrm{SrF}_{2}, \mathrm{BaF}_{2}, \mathrm{SbF}_{3}, \mathrm{BiF}_{3}, \mathrm{LaF}_{3}, \mathrm{NdF}_{3}, \mathrm{HfF}_{4}$ を取りあげ, 4 組成点で 14 種のガラ スを作製し，試料とした。イオン伝導度測定は金の 3 電極を用いて，キャパシタンスブリッジとインピ ーダンスベクトルメーターを併用して, アルゴン雲囲気中で室温からガラス転移温度までの温度領域に ついて行なった。

測定したイオン伝導度の温度依存性は Arrhenius 式により表わすことができ，導電率はほぼ「公導 のための活性化エネルギー」にのみ依存し，逆比例関係にあった。フッ化物イオン伝導を支配すると考 えられる諸因子について導電率との相関性を検討した結果，ガラス構成陽イオンの分極率が導奄率を支 配する主要因子であると結論できた。それゆえ,ガラス中の陽イオンの平均分極率が大きいガラスほど, 伝導のための活性化エネルギーは減少し, 導電率は増大した。そして $\mathrm{ZrF}_{4}-\mathrm{BaF}_{2}-\mathrm{CsF}$ 采がより高いフ ッ化物イオン伝導性ガラスを与えらる系であることが示唆された。

\section{1 腥 言}

電気的機能性物質の探索の一つとして，各種イオンの高伝導性 固体電解質の研究が現在, 活発に進められている。陰イオン层導 種 $\left(\mathrm{F}^{-}, \mathrm{Cl}^{-}, \mathrm{O}^{2-}\right)$ のらち, フッ化物イオンは原子価数が 1 で, イオン半径がもっとも小さいことから，導電率の大きい陰イオン 固体電解質を与えらる伝導種として注目されてきた。結晶でフッ 化物イオン伝導性をもつ化合物の探索は 1970 年代の初めから現 在まで精力的に進められており，結晶構造と導電率との関係のキ ヤラクタリゼーション，そして，それに基づくより高いイオン伝 導性化合物の合成が陚みられ，これまでに導電率の大きい種々の 化合物が見い出されてきている1。

ところで材料物質を結晶質材と非晶質材（代表的にはガラス） に分けて，両者を材料特性的に比較した場合，ガラスでは大型で 複雑な形状の材料が比較的容易に作製・加工できること，粒界が なく，ち密で堅ろらかつ等方的であることなど有利な点が多い。 それゆ兄，フッ化物イオン伝導性物質においても，その導電率に 大美がなければがラス物質の方が結晶物質よりも応用的観点から は好ましい場合が多い。しかし、フッ化物イオン伝導性ガラスの 開発のためにはまず第一に，ガラス化するフッ化物系の探索が先 行しなければならない。

1975 年ころまではフッ化物ガラスとしては $\mathrm{BeF}_{2}$ 系扰よび

神戸大学理学部化学科, 657 神戸方漠区六甲台

1) P. Hagenmuller, W. van Gool, "Solid Electrolytes", Academic Press, New York (1978) p. 313.
$\mathrm{AlF}_{3}$ 釆のガラスが知られていたのみであり，また，そのフっ化 物イオン伝導度は $200^{\circ} \mathrm{C} て ゙ 10^{-10} \mathrm{~S} \cdot \mathrm{cm}^{-1}$ 程度であり 2)3，固体電 解質として期待でさるるのではなく、フッ化物イオンの伝薄性が ラスの開発はあまり考慮されなかった。しかし，1975年に $\mathrm{BeF}_{2}$ 系 ガラスのよらな毒性がなく,一方, $\mathrm{AlF}_{8}$ 系ガラスよりるはるかに ガラス化傾向が大きく種々の元素を含ませらる $\mathrm{ZrF}_{4}$ 系ガラスが 偶然の所産として見いだされだ)。そして、このガラスの導奄害 測定, および Tubandt 法, ブロッキング電原法, emf 法による 輸率測定から， $\mathrm{ZrF}$ 系ガラスは導電率が $200^{\circ} \mathrm{C}$ で約 $10^{-6} \mathrm{~S} \cdot \mathrm{cm}^{-1}$ 前後のフッ化物イオン云導体であることが明らかになっだ58。一 方， $\mathrm{ZrF}_{4}$ 系ガラスの発見後，種々のフッ化物ガラス（たとえば

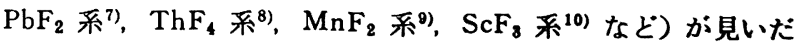

2) E. A. Porai-Koshits, "The Structure of Glass", Vol.6, Consultants Bureau, New York (1966) p. 200.

3) O. V. Mazurin, "The Structure of Glass", Vol. 4, Consultants Bureau, New York (1965) p. 88.

4) M. Poulain, M. Poulain, J. Lucas, Mater. Res. Bull., 10, 243(1975).

5) D. Leroy, J. Lucas, M. Poulain, D. Ravaine, ibid., 13, 1125(1978).

6) D. Ravaine, D. Leroy, J. Non-Cryst. Solids, 38 \& 39, 575(1980).

7) J.P. Miranday, C. Jacoboni, R. de Pape, Rev. Chim. Miner., 16, 277(1979).

8) J. Lucas, H. Slim, G. Fonteneau, J. Non-Cryst. Solids, 44, 31(1981).

9) Y. L. Page, G. Fonteneau, J. Lucas, Mater. Res. Bull., 17, 647(1982). 
Table 1 Compositions, glass transition temperatures $\left(T_{\mathrm{g}}\right)$, densities $(d)$, ionic conductivities at $200 \mathrm{C}\left(\log \sigma_{200^{\circ} \mathrm{C}}\right)$, preexponential terms $\left(\log \sigma_{0}\right)$, and activation energies $(J E)$ of $\mathrm{Z}_{2} \mathrm{~F}_{4}-\mathrm{BaF}_{2}-\mathrm{MF}_{n}$ glasses

\begin{tabular}{ccccccc} 
Glass & Composition/mol\% & $T_{\mathrm{g}} /{ }^{\circ} \mathrm{C}$ & $d / \mathrm{g} \cdot \mathrm{cm}^{-8}$ & $\begin{array}{c}\log \left(\sigma_{200^{\circ} \mathrm{C} /}\right. \\
\left.\mathrm{S} \cdot \mathrm{cm}^{-1}\right)\end{array}$ & $\begin{array}{c}\log \left(\sigma_{0} /\right. \\
\left.\mathrm{S} \cdot \mathrm{cm}^{-1}\right)\end{array}$ & $\Delta E / \mathrm{eV}$ \\
\hline $\mathrm{Ca}$ & $65 \mathrm{ZrF}_{4} \cdot 25 \mathrm{BaF}_{2} \cdot 10 \mathrm{CaF}_{2}$ & 311 & 4.47 & -5.58 & 2.54 & 0.76 \\
$\mathrm{Sr}$ & $65 \mathrm{ZrF}_{4} \cdot 25 \mathrm{BaF}_{2} \cdot 10 \mathrm{SrF}_{2}$ & 292 & 4.43 & -5.22 & 2.65 & 0.74 \\
$\mathrm{Ba}$ & $65 \mathrm{ZrF}_{4} \cdot 25 \mathrm{BaF}_{2} \cdot 10 \mathrm{BaF}_{2}$ & 303 & 4.70 & -5.10 & 2.77 & 0.74 \\
$\mathrm{La}$ & $62 \mathrm{ZrF}_{4} \cdot 30 \mathrm{BaF}_{2} \cdot 8 \mathrm{LaF}_{3}$ & 312 & 4.70 & -5.26 & 2.52 & 0.73 \\
$\mathrm{Na}$ & $59 \mathrm{ZrF}_{4} \cdot 26 \mathrm{BaF}_{2} \cdot 15 \mathrm{NaF}$ & 254 & 4.49 & -5.38 & 2.95 & 0.78 \\
$\mathrm{Rb}$ & $59 \mathrm{ZrF}_{4} \cdot 26 \mathrm{BaF}_{2} \cdot 15 \mathrm{RbF}$ & 270 & 4.29 & -5.23 & 2.47 & 0.72 \\
$\mathrm{Cs}$ & $59 \mathrm{ZrF}_{4} \cdot 26 \mathrm{BaF}_{2} \cdot 15 \mathrm{CsF}$ & 268 & 4.48 & -4.98 & 2.58 & 0.71 \\
$\mathrm{Sb}$ & $59 \mathrm{ZrF}_{4} \cdot 26 \mathrm{BaF}_{2} \cdot 15 \mathrm{SbF}_{3}$ & 289 & 4.47 & -5.39 & 2.56 & 0.75 \\
$\mathrm{Bi}$ & $59 \mathrm{ZrF}_{4} \cdot 26 \mathrm{BaF}_{2} \cdot 15 \mathrm{BiF}_{3}$ & 295 & 4.64 & -5.12 & 2.65 & 0.73 \\
$\mathrm{Nd}$ & $59 \mathrm{ZrF}_{4} \cdot 26 \mathrm{BaF}_{2} \cdot 15 \mathrm{NdF}_{3}$ & 326 & 4.72 & -5.27 & 2.36 & 0.72 \\
$\mathrm{Hf}$ & $59 \mathrm{ZrF}_{4} \cdot 26 \mathrm{BaF}_{2} \cdot 15 \mathrm{HfF}_{4}$ & 292 & 4.84 & -5.35 & 2.74 & 0.76 \\
$\mathrm{Li}$ & $55 \mathrm{ZrF}_{4} \cdot 20 \mathrm{BaF}_{2} \cdot 25 \mathrm{LiF}$ & 230 & 4.24 & -5.58 & 3.09 & 0.81 \\
$25 \mathrm{Na}$ & $55 \mathrm{ZrF}_{4} \cdot 20 \mathrm{BaF}_{2} \cdot 25 \mathrm{NaF}$ & 235 & 4.23 & -5.74 & 2.95 & 0.82 \\
$25 \mathrm{Cs}$ & $55 \mathrm{ZrF}_{4} \cdot 20 \mathrm{BaF}_{2} \cdot 25 \mathrm{CsF}$ & 249 & 4.33 & -4.85 & 2.58 & 0.70
\end{tabular}

されるにおよんで, 高いフッ化物イオン层導度をもつガラスの開 発の可能性が大きくなり，数年前からフッ化物イオン伝導性ガラ スの研究が開始され始めた ${ }^{11) ~ 15) 。 ~}$

ZrF、系ガラスについていえば，これまでに見いたされている

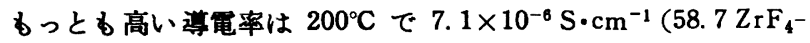
31. $3 \mathrm{BaF}_{2}-10.0 \mathrm{ThF}_{4}$ ガラス) である5)。そして, フッ化物イオ ンの层導性を高めうる要因はフッ化物イオンのルーズな充填, お。 よびジルコニウムの高フッ素配位数とその配位形態の多様性であ るとされている16)。しかし，研究は端緒についたばかりであり，

より高い導電率をるつ $\mathrm{ZrF}_{4}$ 系ガラスの開発の方向づけやフッ化 物イオンの云導機構の解明には，まだまだ多くの研究が必要であ る。著者と共同研究者は数年前から， $\mathrm{ZrF}_{4}$ 系カラスの構造研究

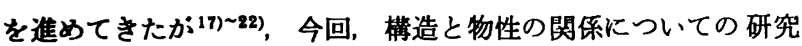
の一つとして，ZrF、釆ガラスでのフッ化物イオン伝導のキャラ クタリセーションを試みることにした。本研究では, その第一段

10) M. Poulain, M. Poulain, M. Matecki, Mater. Res. Bull., 17, 661 (1982).

11) C. M. Baldwin, J. D. Mackenzie, J. Non-Cryst. Solids, 42, 455(1980).

12) D. Ravaine, ibid., 40, 209(1980).

13) D. Ravaine, W. G. Perera, M. Minier, J. Phys., 43, C 9-407(1982).

14) R. M. Almeida, J. D. Mackenzie, J. Mater. Sci., 17, 2533(1982).

15) J. Guery, G. Courbion, C. Jacoboni, R. de Pape, Mater. Res. Bull., 19, 1437(1984).

16) D. Ravaine, G. Perera, M. Poulain, Solid State Ionics, $9 \&$ 10, 631(1983).

17) Y. Kawamoto, F. Sakaguchi, Bull. Chem. Soc. Jpn., 56, 2138(1983).

18) Y. Kawamoto, T. Horisaka, J. Non-Cryst. Solids, 56, 39(1983).

19) Y. Kawamoto, Phys. Chem. Glasses, 25, 88(1984).

20) Y. Kawamoto, T. Horisaka, K. Hirao, N. Soga, Chem. Lett., 1984, 1441,

21) Y. Kawamoto, I. Nohara, K. Hirao, N. Soga, Solid State Commun., 51, 769(1984).

22) Y. Kawamoto, T. Horisaka, K. Hirao, N. Soga, J. Chem. Phys., 83, 2398 (1985).
階としてガラス組成（ガラス棤成成分）と導電率との関係につい て検討を行なった。

\section{2 実験}

\section{1 ガラス試料の作製}

本研究に用いたガラスは $\mathrm{ZrF}_{4}-\mathrm{BaF}_{2}$ 系に第 3 成分として 12 種 類の金属フッ化物, $\mathrm{MF}_{n}(\mathrm{M}: \mathrm{Li}, \mathrm{Na}, \mathrm{Rb}, \mathrm{Cs}, \mathrm{Ca}, \mathrm{Ba}, \mathrm{Sr}, \mathrm{Sb}$, $\mathrm{Si}, \mathrm{La}, \mathrm{Nd}, \mathrm{Hf})$ を添加した $\mathrm{ZrF}_{4}-\mathrm{BaF}_{2}-\mathrm{MF}_{n}$ 三成分ガラスで ある。作製したガラス試料は 14 種類で，それらの組成は表 1 に 示してある。14種のガラスは組成上，図1に示すように，四つの 組成グループ，(A) $65 \mathrm{ZrF}_{4}-25 \mathrm{BaF}_{2}-10 \mathrm{MF}_{n}$ (モル\%) (M:Ca, $\mathrm{Sr}, \mathrm{Ba})$, (B) $62 \mathrm{ZrF}_{4}-30 \mathrm{BaF}_{2}-8 \mathrm{MF}_{n}(\mathrm{M}: \mathrm{La})$, (C) $59 \mathrm{Zr}$. $\mathrm{F}_{4}-26 \mathrm{BaF}_{2}-15 \mathrm{MF}_{n}(\mathrm{M}: \mathrm{Na}, \mathrm{Rb}, \mathrm{Cs}, \mathrm{Sb}, \mathrm{Bi}, \mathrm{Nd}, \mathrm{Hf}),(\mathrm{D})$

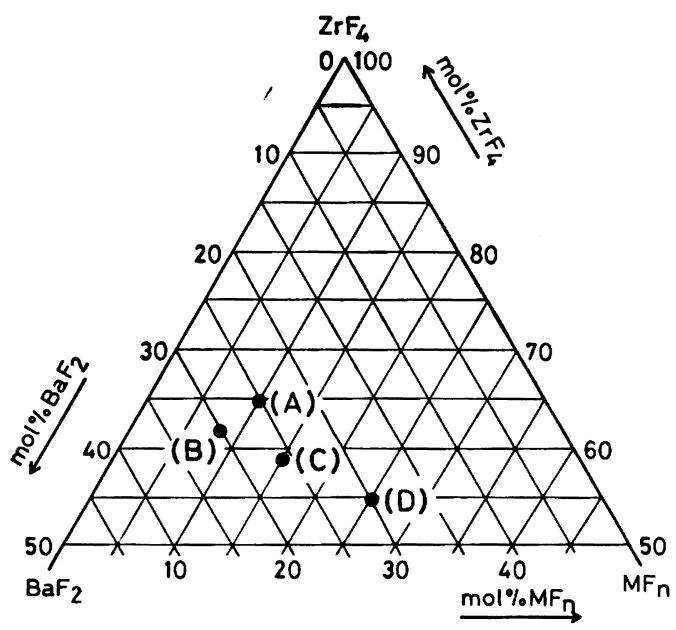

Fig. 1 Location of $\mathrm{ZrF}_{4}-\mathrm{BaF}_{2}-\mathrm{MF}_{n}$ glass samples in ternary phase diagram

(A) : $\mathrm{MF}_{n}=\mathrm{CaF}_{2}, \mathrm{SrF}_{2}$, and $\mathrm{BaF}_{2}$

(B) : $\mathrm{MF}_{n}=\mathrm{LaF}_{3}$

(C) : $\mathrm{MF}_{n}=\mathrm{NaF}, \mathrm{RbF}, \mathrm{CsF}, \mathrm{SbF}_{3}, \mathrm{BiF}_{3}, \mathrm{NdF}_{3}$, and $\mathrm{HfF}_{4}$

(D) : $\mathrm{MF}_{n}=\mathrm{LiF}, \mathrm{NaF}$, and $\mathrm{CsF}$ 
$55 \mathrm{ZrF}_{4}-20 \mathrm{BaF}_{2}-25 \mathrm{MF}_{n}(\mathrm{M}: \mathrm{Li} ， \mathrm{Na}, \mathrm{Cs})$ に分けられる。本 米ならば，籍 3 成分 $\mathrm{MF}_{n}$ を比較的多量に含む組成, たとえば上 讪 (D) の組成ですべての $\mathrm{ZrF}_{4}-\mathrm{BaF}_{2}-\mathrm{MF}_{n}$ ガラスを準備する ことが本研究の目的のためには望ましいが，第 3 成分のフッ化物 便によりガラス形成能がいちじるしく異なったため, 上記の 4 組 成にわけてガラス試料を準借せさるをえなかった。

ガラス作製の原料試楽としては， $\mathrm{ZrF}_{4}$ と $\mathrm{HfF}_{4}$ 成分について は，それぞれ $\left(\mathrm{NH}_{4}\right)_{2} \mathrm{ZrF}_{6}$ と $\left(\mathrm{NH}_{4}\right)_{2} \mathrm{HfF}_{6}$ を， $\mathrm{NdF}_{8}$ 成分につ いては $\mathrm{Nd}_{2} \mathrm{O}_{3}$ を，そして，それ以外の成分についてはそれぞれ の金属フッ化物を用いた。なお，試薬の純度は特級試薬級または 一級試楽級である。ガラスの作製はつぎのようにして行なった。 それぞれの原料試薬を組成比の割合で全量が約 $5 \mathrm{~g}$ になるように 科取し，これにガラス成分原料のフッ化を完全にするためのフッ 化剂として $\mathrm{NH}_{4} \mathrm{HF}_{2}$ を約 $1 \mathrm{~g}$ 添加したものをバッチとした。溶

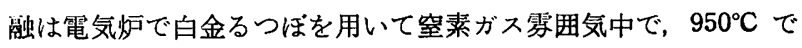
20 分間行なった。溶融後, 融液を $100^{\circ} \mathrm{C}$ 前後に加熱した黄銅板 でプレス急冷して, 厚さ約 $0.5 \sim 1 \mathrm{~mm}$ の薄板状ガラス試料を得 た。そして，この急冷ガラスをDTA 湘定により求めたガラス転 移温度（表 1 に記載）に 1 時間保持してひずみを除き，つぎに述 べる密度および導電率の測定試料とした。

\section{2 密度測定}

ガラスの密度は四塩化炭素を侵液として, Archimedes 法で測 定した。 $20^{\circ} \mathrm{C}$ での密度を表 1 に記す。

\section{3 埒電率測定}

加水分解を防ぐため，ガラスをオイル中で平行かつ鏡面に成形 研磿し, 導電率测定用試料とした。表面を洗浄後、スパッタリン グ法で金電極を取りつけ，3電極法でキャパシタンスブリッジ （安藤電気製 TR-1C 型）およびインピーダンスベクトルメータ 一(HP 製 4800 A) を併用して, アルゴンガス雾囲気中で室温 からガラス転移温度までの温度範囲について導電率を測定した。 キャパシタンス法とインピーダンス法での 測定結果の一例を 59 $\mathrm{ZrF}_{4}-26 \mathrm{BaF}_{2}-15 \mathrm{CsF}$ ガラスについて図 2 に示す。

\section{3 結果亡考察}

図 3 は測定した 14 種類のガラスのイオン伝導度の温度依存性 を示したもので, 测定温度領域では Arrhenius 式

$$
\sigma=\sigma_{0} \exp (-\Delta E / k T)
$$

にしたがっている。ここで $\sigma_{0}$ は前指数項， $\Delta E$ は伝導のための

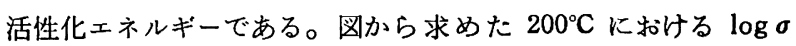
(今後 $\log \sigma_{200}{ }^{\circ} \mathrm{C}$ と略記する), $\log \sigma_{0}$ および $\Delta E$ の值を表 1 に 示す。また，図 4 には同組成での導電率への $\mathrm{MF}_{n}$ 成分の影艟を みるために $200^{\circ} \mathrm{C}$ での $\sigma$ の值をガラス組成グループごとにまと めて示してある。

図4に拈いて，Aグループでの第 3 成分 $\mathrm{CaF}_{2}, \mathrm{SrF}_{2}, \mathrm{BaF}_{2}$ は その結晶構造は同型（ホタル石型）であり，またCとDのグルー プでの第 3 成分 $\mathrm{LiF}, \mathrm{NaF}, \mathrm{RbF}, \mathrm{CsF}$ もと結晶構造は同型

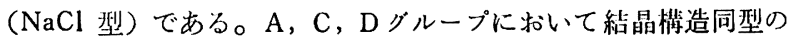
第 3 成分を含むガラスの $\sigma_{200{ }^{\circ} \mathrm{C}}$ の值の比校から, 第 3 成分 $\mathrm{MF}_{n}$ のMの原子番号が大きいほど，そのガラスの導電犁は大きいこと

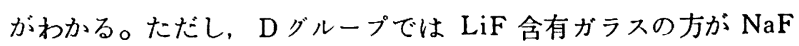
含有ガラスより導電率がわずか大きい。これは LiF 含有ガラス ではフッ化物イオン伝導と同時にリチウムイオン伝導が生じてい
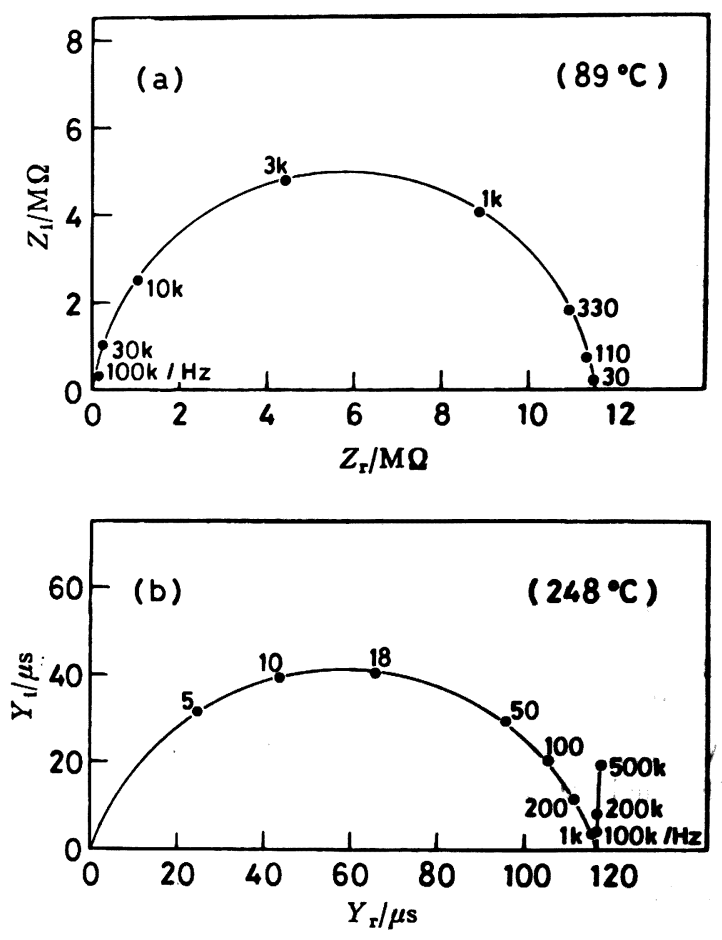

Fig. 2 Complex capacitance (a) and complex impedance (b) plots for $59 \mathrm{ZrF}_{4}-26 \mathrm{BaF}_{2}-15 \mathrm{CsF}$ glass

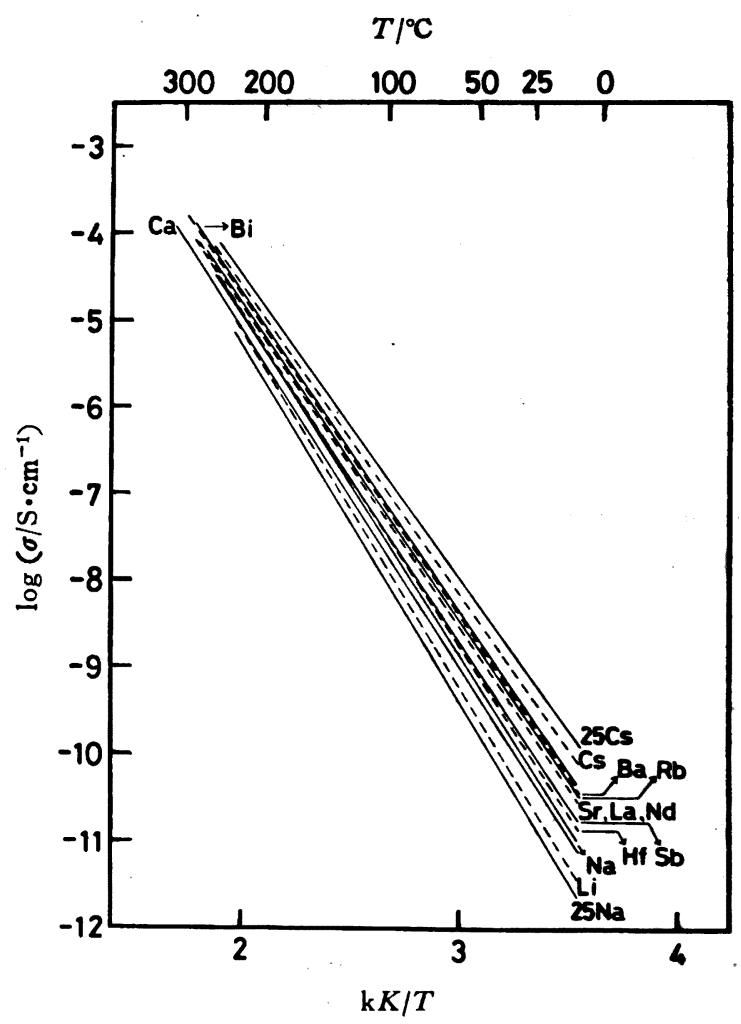

Fig. $3 \log \sigma$ vs. $1 / T$ for $\mathrm{ZrF}_{4}-\mathrm{BaF}_{2}-\mathrm{MF}_{n}$ glasses

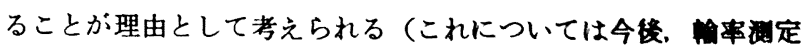
などで確かめる予定である)。一方，Cクルーブでの $\mathrm{SbF}_{3}, \mathrm{BiF}_{3}$, $\mathrm{NdF}_{3}$ は 3 価陽イオンのフッ化物であるが，同じ族のフッ化物で 


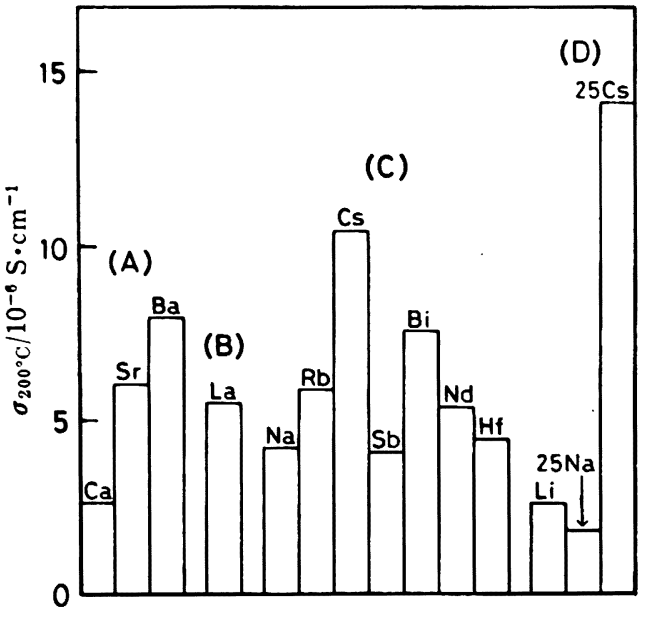

Fig. 4 Ionic conductivities at $200^{\circ} \mathrm{C}$ of $\mathrm{Z}_{\mathrm{rF}_{4}}-\mathrm{BaF}_{2}-\mathrm{MF}_{n}$ glasses

(A) : $10 \mathrm{~mol} \% \mathrm{MF}_{n}$, (B) : $8 \mathrm{~mol} \% \mathrm{MF}_{n}$, (C) $: 15 \mathrm{~mol} \%$ $\mathrm{MF}_{n}$, and (D) : $25 \mathrm{~mol} \% \mathrm{MF}_{n}$

ないためか、あるいは結晶構造が異なるためか明確な傾向は認め られない。

つぎに，ZrF4 系ガラスでのフッ化物イオン伝導を支配する因 子について考察する。ここでは支配因子として，（1）単位体積 あたりのフッ化物イオン濃度, $C_{\mathrm{F}}, （ 2 ） フ ッ$ 化物イオン間の平 均距離, $\overline{a_{\mathrm{F}}}$, （3）単位体積あたりの自由体積, $V_{\mathrm{F}}$, （4）ガラス 構成陽イオンとフッ化物イオンの単結合強度の平均值, $E_{\mathrm{M}-\mathrm{F}}$, 拧 よび（5）ガラス構成陽イオンの分極率の平均值， $\alpha_{\mathrm{M}}$ を考える ことにした。これら 5 種の因子はガラスの導電率を Arrhenius 式(1)で表わした場合, 前指数項 $\sigma_{0}$ と活性化エネルギー $\Delta E$ K 対して

$$
\begin{aligned}
& \sigma_{0} \propto C_{\mathrm{F}} \cdot{\overline{a_{\mathrm{F}}}}^{2} \cdot V_{\mathrm{F}} \\
& \Delta E \propto\left(\overline{E_{\mathrm{M}-\mathrm{F}}}+\overline{\alpha_{\mathrm{M}}}\right)
\end{aligned}
$$

のように関係つけられるであろら”。それゆえ最初に, “ $\log \sigma_{200^{\circ}} \mathrm{C}$ と $\log \sigma_{0} ”$ および “ $\log \sigma_{200}{ }^{\circ} \mathrm{C}$ と $\Delta E^{n}$ との相関性を求め, つぎ に“ $\log \sigma_{0}$ と $\log C_{\mathrm{F}}, \log {\overline{a_{\mathrm{F}}}}^{2}, \log V_{\mathrm{F}}$ のそれぞれ”との相関性, “ $\Delta E$ と $\overline{E_{\mathbf{M - F}}}, \overline{\alpha_{\mathbf{M}}}$ のそれぞれ”との相関性を求めてみた。ここ で $C_{\mathbf{F}}, \overline{a_{\mathrm{F}}}, V_{\mathrm{F}}$ はガラスの組成, 密度および各イオンの半径から 算出した。なお, 各イオンの半径は Shannon と Prewitt の 値 ${ }^{23)}$ を用いた(イオン半径值はフッ化物イオンの配位数により多 少異なるので, とりあえず $\mathrm{Li}, \mathrm{Na}, \mathrm{Ca}, \mathrm{Sb}, \mathrm{Bi}$ についていッ 素六眍位の, Rb, La, Nd, Hf は八配位の, $\mathrm{Sr}, \mathrm{Ba}$ について 十配位の，そしてCsについては十二配位のものを用いた)。つ きに $\overline{E_{M-F}}$ を求めるさいに必要なそれぞれの陽イオンの $E_{\mathrm{M}-\mathrm{F}}$ の値は Baldwin と Mackenzie の論文 ${ }^{24)}$ から採用した(なお， 論文に不記载の $E_{\mathrm{Rb}-\mathrm{F}}$ と $E_{\mathrm{La}-\mathrm{F}}$ の值はそれぞれ $E_{\mathrm{K}-\mathrm{F}}$ と $E_{\mathrm{Nd}-\mathrm{F}}$ と同し值を用いた)。さらに， $\alpha_{M}$ を求めるために必要な各イオン

23) R. D. Shannon, C. T. Prewitt, Acta Cryst., B 25, 925 (1969).

24) C. M. Baldwin, J. D. Mackenzie, J. Am. Ceram. Soc., 62, $537(1979)$.

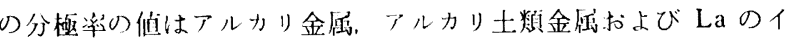
オンについては文献值 ${ }^{25)}$ を，そして Sb, Bi, Nd, Zr, Hf につい ては文献での記載イオンの分極率の周期律傾向から,とりあえず, それぞれ $1.60 ， 2.80,1.09,0.51 ， 0.53 \AA^{3}$ と見糟って用いた。

図 5 は $\log \sigma_{200^{\circ} \mathrm{C}}$ の $\log \sigma_{0}$ および $\Delta E$ との相関性を示したも のである。相関係数値は前者が 0.48 , 後者が 0.88 で, 㧭電率は 伝装のための活性化エネルギーに大きく支亚されていることがわ かった。そして, $\log \sigma_{0}$ と $\log C_{\mathrm{F}}, \log {\overline{a_{\mathrm{F}}}}^{2}, \log V_{\mathrm{F}}$ との相関を 求めたところ，相関係数値はそれぞれ，0.30，0.30，0.06であり， 相関関係があるとはいえなかった。一方， $\Delta E$ と $\overline{E_{\mathrm{M}-\mathrm{F}}}, \overline{\alpha_{\mathrm{M}}}$ と の相関係数值はそれぞれ，0.21 と 0.88 であった。図 6 に $\Delta E$ と $\alpha_{\mathrm{M}}$ との相関性を示す。以上のことから, 前指数項 $\sigma_{0}$ を支配 する主要因子は明確でないが，活性化ェネルギー $\Delta E$ 值はガラ ス棈成陽イオンの平均分極染に大きく依存することが明らかにな った。

ところで, Ravaine ら ${ }^{6)}$ は種々の組成のフッ化物ガラスのイオ ン伝導度を测定し，ガラス中でのフッ化物イオンのルーズな充填 が導電率を高めるといっている。いいかえると，導電率はフッ化 物イォン濃度に直接，相関関係があるとしている。試みに今回測 定したガラスについて $\log \sigma_{200}{ }^{\circ} \mathrm{C}$ と $\log C_{\mathrm{F}}$ との相関性を求めて みると図 7 のよらになり，その相関係数値は 0.65 となった。一
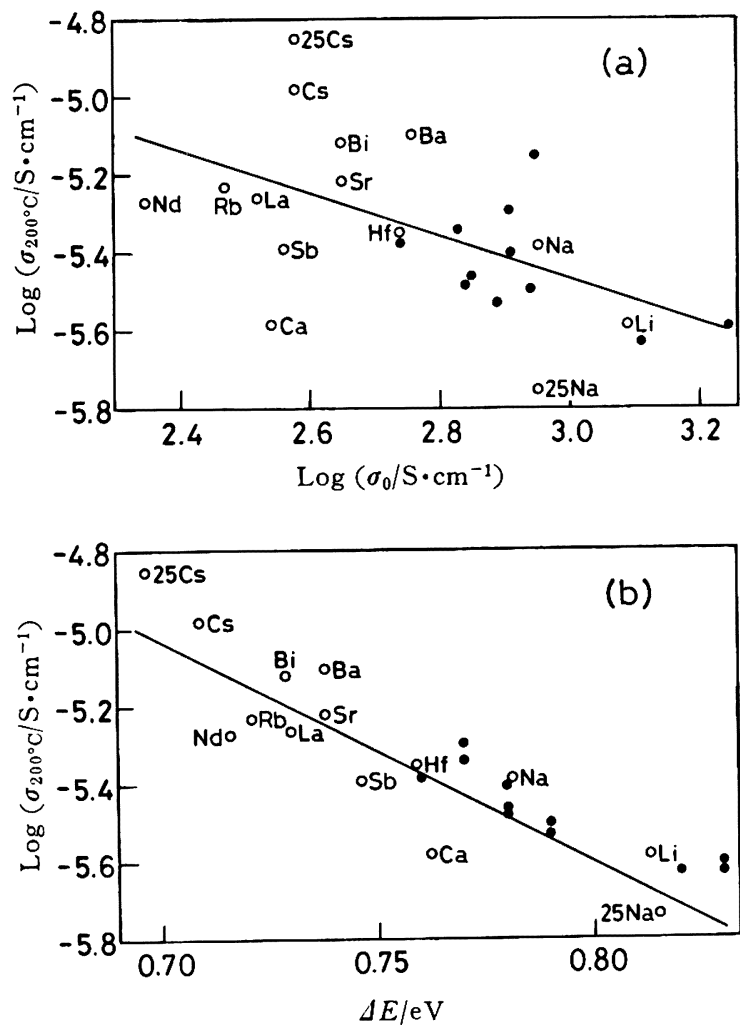

Fig. 5 Dependence of $\log \sigma_{200^{\circ} \mathrm{C}}$ on $\log \sigma_{0}$ (a) and $\Delta E$ ( b )

$: \mathrm{ZrF}_{4}-\mathrm{BaF}_{2}-\mathrm{MF}_{2} \quad(\mathrm{M}: \mathrm{La}, \quad \mathrm{Nd}, \mathrm{Pr}, \quad$ and $\mathrm{Th})$ glasses of Ref. 5

25）桐川良一，柯山秀子，“㔍造無機化学Ｉ”，第 3 版，共站出 版（1979） p. 242 


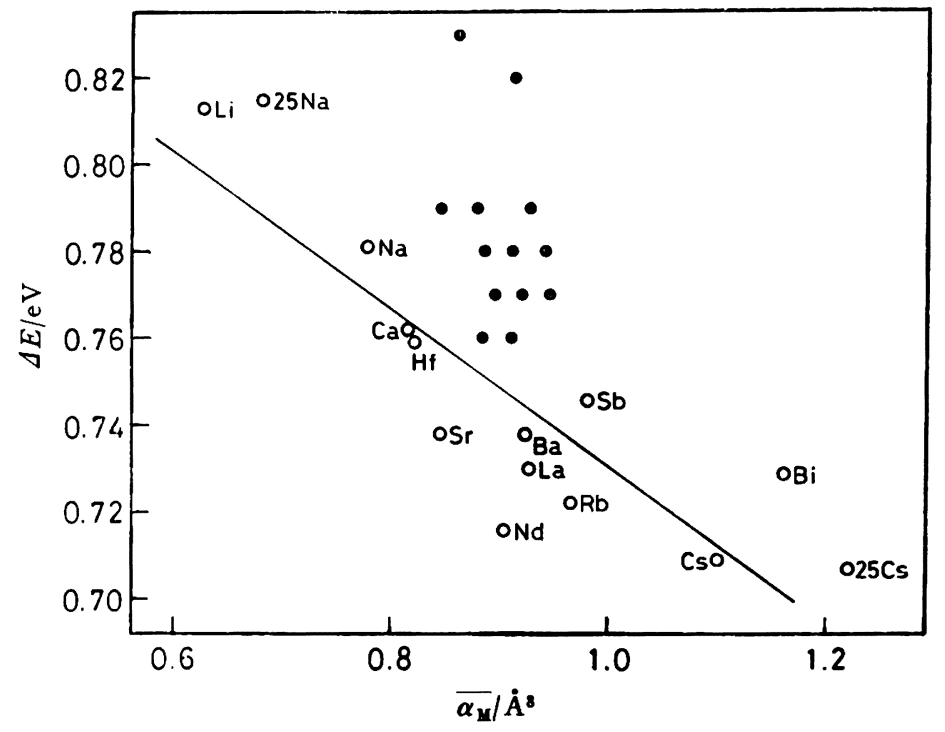

Fig. 6 Dependence of $\Delta E$ on $\overline{\alpha_{M}}$

$: \mathrm{ZrF}_{4}-\mathrm{BaF}_{2}-\mathrm{MF}_{n}(\mathrm{M}: \mathrm{La}, \mathrm{Nd}, \mathrm{Pr}$, and $\mathrm{Th}$ ) glasses of Ref. 5)

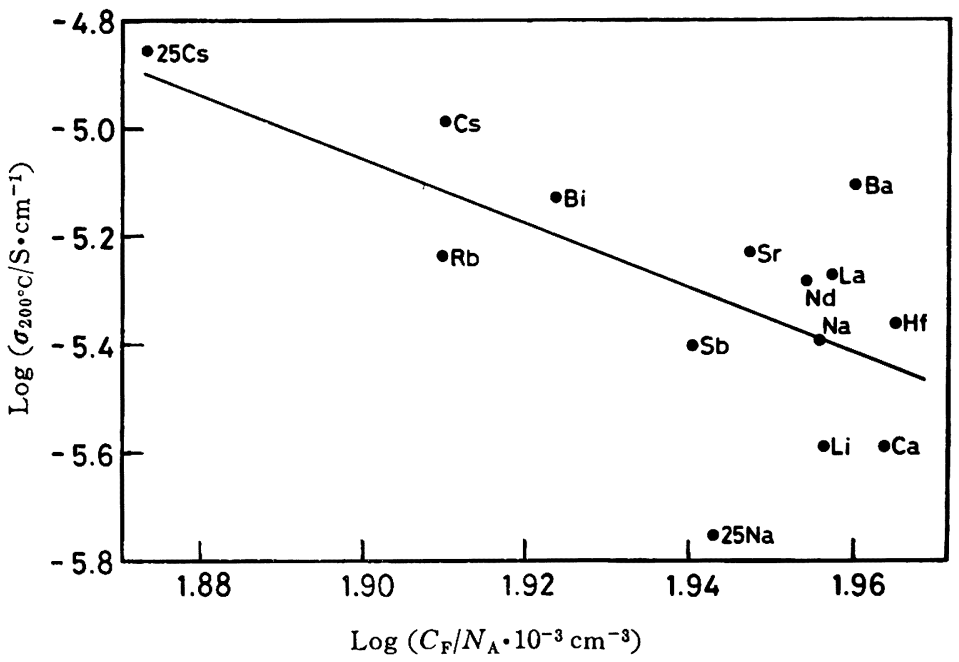

Fig. 7 Dependence of $\log \sigma_{200^{\circ} \mathrm{C}}$ on $\log C_{F}$

方，本考察で得られた結論にもとついて， $\log \sigma_{200^{\circ} \mathrm{C}}$ と $\alpha_{\mathrm{M}}$ との 直接の相関性を求めると四 8 のようになり，その相関係数值は 0.87であった。これから，フッ化物イオン濃度は $\mathrm{ZrF}_{4}$ 系がラ スのフッ化物イオン伝導度を支配する一因子であると考えること もできるが，ガラス䌖成陽イオンの平均分極率がフッ化物イオン 伝導度を支配する主因子と結論する方が論理的に妥当であるとい える。四5(B) と四 6 にLeroy ら5が测定した $\mathrm{ZrF}_{4}-\mathrm{BaF}_{2}$ $\mathrm{MF}_{n}(\mathrm{M}: \mathrm{La}, \mathrm{Nd}, \mathrm{Pr}, \mathrm{Th})$ 系ガラスの導電率データが本研究 で得られた関係にどの程度合致するかを四示した。四からわかる よらに,かなりよい合致が認められる。

ところで，比較的大きいフッ化物イオン伝導性を示すフッ化物 結晶は結晶構造上, チソナイト $\left(\mathrm{LaF}_{3}\right)$ 型, フッ化イットリウム $\left(\mathrm{YF}_{3}\right)$ 型，ホタル石 $\left(\mathrm{CaF}_{2}\right)$ 型のいずれかの絬晶型に属してお り，導電摔と結晶蓝造㧍よび化学組成との関係から，フッ化物イ
オン伝導度は，（1）陽イオンの分極率が大きいと，（2）陽イ オンとフッ化物イオンの結合強度が弱いほど，（3）陽イオンの フッ化物イオン配位数が大きいほと，（4）フッ化物イオン银度 とフッ化物イオン空孔の割合（非化学量論比）が適当な条件下に あるとき，高められるとされている ${ }^{26)}$ 。れれゆえ，本研究で“ガ ラス構成陽イオンの平均分極率が $\mathrm{ZrF}_{4}$ 系ガラスでのフッ化物イ オン伝導度を支配する”という結論が得られたことは不合理では ないといえままた興味深い。そして，この結論は陽イオンが变形 しやすいほど、フッ化物イオンの移動が容易であることを意味し ている。

これまでに報告されている $\mathrm{ZrF}$ 系ガラスにおいて，影高の辛 電率は，緒言でも記したように，58. $7 \mathrm{ZrF}_{4} ・ 31.3 \mathrm{BaF}_{2} ・ 10.0 \mathrm{Th}$

26) P. Hagenmuller, J. M. Reau, C. Lucat, S. Matar, G. Villeneuve, Solid State Ionics, 3/4. 341(1981). 


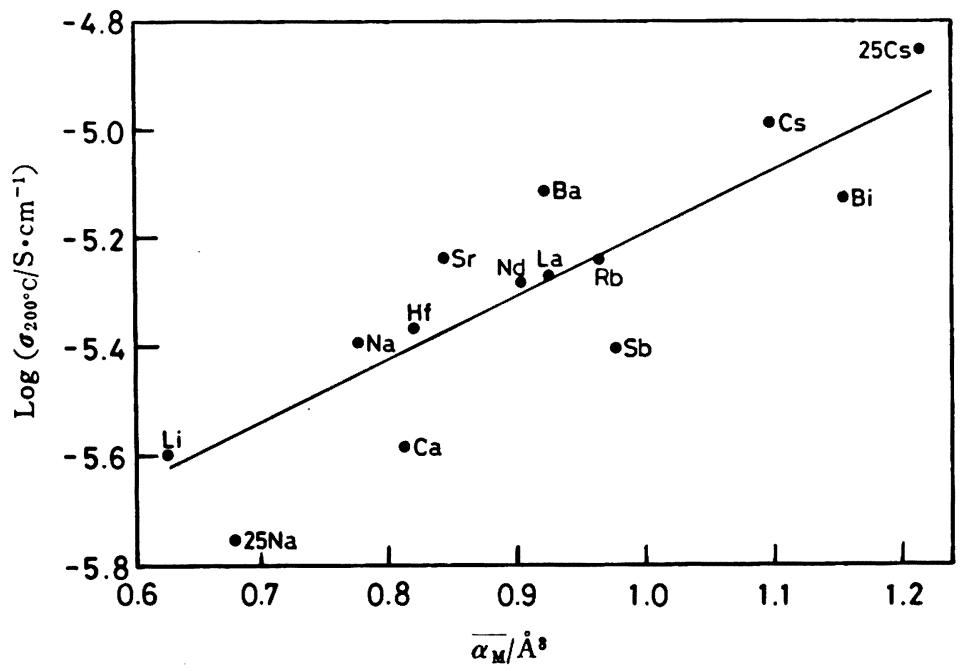

Fig. 8 Dependence of $\log \sigma_{200^{\circ} \mathrm{C}}$ on $\overline{\alpha_{M}}$

F、ガラスの $200^{\circ} \mathrm{C} て ゙ 7.10 \times 10^{-6} \mathrm{~S} \cdot \mathrm{cm}^{-1}$ である5)。今回測定した

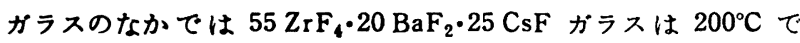
$1.41 \times 10^{-5} \mathrm{~S} \cdot \mathrm{cm}^{-1}$ の满電率を示し，上記のものよりわずかであ ろが大きい。しし，この導电率值もフッ化物イオン伝尊性結晶 のそれらと比较すれば，尊軍率の非常に悪い $\alpha-\mathrm{PbF}_{2}\left(\mathrm{PbCl}_{2}\right.$ 型 棈造）の值と同程度であり，高い道䉓率を示す $\beta-\mathrm{PbSnF}_{4}$ や $\mathrm{Rb}$ $\mathrm{BiF}_{4}$ (ともKホタル石型構造) の值とくらべると約 3 ケタ程度小 さい20)。

$\mathrm{ZrF}$ 系ガラスの您電率をさらに高めるためには, $\mathrm{ZrF}_{4}-\mathrm{BaF}_{2}$ CsF 秋たいて，陽イオンの平均分極率のより大きいガラスの作

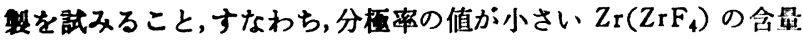
を減少させたガラスを作製することが一つの方法と考えられる。

\section{4 結 销}

$\mathrm{ZrF}_{4}-\mathrm{BaF}_{2}$ 禾K $\mathrm{LiF}, \mathrm{NaF}, \mathrm{RbF}, \mathrm{CsF}, \mathrm{CaF}_{2}, \mathrm{SrF}_{2}, \mathrm{BaF}_{2}$, $\mathrm{SbF}_{3}, \mathrm{BiF}_{3}, \mathrm{LaF}_{3}, \mathrm{NdF}_{3}$, および $\mathrm{HfF}_{4}$ の金属フッ化物を第 3
成分として添加した $\mathrm{ZrF}_{4}-\mathrm{BaF}_{2}-\mathrm{MF}_{n}$ 三成分系ガラスについて イオン伝遒度を测定し，ガラス構成成分と導電率との関係を調べ た。

その結果, 導電率の対数值は伝尊のための活性化エネルギー值 と逆比例関係にあり, 他方, 活性化ェネルギー值はガラス橏成陽 イオンの平均分極率の值と逆比例関係にあることがわかった。そ れゆえ，ガラス構成陽イオンの平均分極率が大きいガラスほど， 大きい導電率を示すことが明らかになった。そして本研究で取り 扱った系の中では， $\mathrm{ZrF}_{4}-\mathrm{BaF}_{2}-\mathrm{CsF}$ 系は大きい陽イオン平均分 極率をもつガラス，すなわち高いフッ化物イオン伝頭性ガラスで あることが判明した。

釉りに，本研然は大行和親記念财団の研究助成のもとに行なわ れたこと，また尊電率测定にさいしては大阪工業技術武験所第四

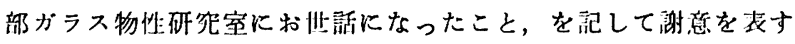
る。

\title{
Special Articles on Fluorine Chemistry and Its Application
}

\author{
lonic Conductivity of $\mathrm{ZrF}_{4}-\mathrm{BaF}_{2}-\mathrm{MF}_{n}$ Fluoride Glasses \\ (M: The Group I $\sim \mathrm{V}$ Metal Elements) \\ Yoji Kawamoto* and Ichiro Nohara \\ Department of Chemistry, Faculty of Science, Kobe University; \\ Rokkodai, Nada-ku, Kobe-shi 657 Japan
}

Ionic conductivity measurements of $\mathrm{ZrF}_{4}-\mathrm{BaF}_{2}-\mathrm{MF}_{n}$ fluoride glasses were carried out to examine the relationship between glass-constituents and fluoride-ion conduction in fluorozirconate glasses. Twelve metal fluorides such as $\mathrm{LiF}, \mathrm{NaF}, \mathrm{RbF}, \mathrm{CsF}, \mathrm{CaF}_{2}, \mathrm{SrF}_{2}, \mathrm{BaF}_{2}$, $\mathrm{SbF}_{3}, \quad \mathrm{BiF}_{3}, \quad \mathrm{LaF}_{3}, \quad \mathrm{NdF}_{3}$, and $\mathrm{HfF}_{4}$ were chosen as the $\mathrm{MF}_{n}$ components and fourteen kinds of glasses in four compositions were submitted to the ionic conductivity measurements. The measurements were carried out in the temperature range from room temperature 
to glass transition temperature in argon atmosphere using the complex capacitance and complex impedance methods.

The ionic conductivity of glasses, represented by $\log \sigma=\log \sigma_{0}-\Delta E / 2.303 \mathrm{kT}$, was nearly dependent only upon the activation energy. The polarizability of cation was found to be a dominant factor which governs activation energy. Thus, glasses with high meanpolarizability of glass-constituting cations exhibited high ionic conductivity, and the $\mathrm{ZrF}_{4}-$ $\mathrm{BaF}_{2}-\mathrm{CsF}$ system was suggested to be a promising system that may provide a glass with higher fluoride-ion conduction. 